\section{Antibiotic susceptibility pro- files of ropy slime-producing Leuconostoc mesenteroides isolated from cooked meat products}

\author{
Maria F. Iulietto, Paola Sechi, Elena \\ Borgogni, Beniamino T. Cenci Goga \\ Department of Veterinary Medicine, \\ Laboratory of Animal Origin Aliment \\ Inspection, University of Perugia, Italy
}

\begin{abstract}
The transfer of antibiotic resistance via the food chain is a global concern. Nevertheless, more attention is required to non-pathogenic strains, such as spoilage bacteria, which could transmit genes to pathogens. Although Lactic Acid Bacteria are microorganisms generally recognized as safe, Leuconostoc mesenteroides may reach and maintain high concentration levels on the surface of cooked products and ready-to-eat products throughout the entire shelf life. It is therefore important to consider the possibility for this species to carry antibiotic-resistance genes. The present research deals with the antibiotic susceptibility profile of strains of $L$. mesenteroides, isolated from vacuum packaged cooked meat products. In this study, the antimicrobial susceptibility of L.mesenteroides, previously isolated from cooked ham, was investigated through disk diffusion assay according to CLSI standards. Isolated strains from ready-to-eat food show high levels of resistance to ampicillin and methicillin and, according to a settled panel of 21 antibiotics, the antibiotic resistance was demonstrated for the $50 \%$ of the tested molecules.
\end{abstract}

\section{Introduction}

Since 1945, the effects of antibiotics misuse were predicted by Alexander Fleming, who foresaw that the antimicrobial selective pressure would have led to the rise of antibiotic resistance in bacteria. ${ }^{1-3}$ The rapid spread of antimicrobial resistance represents a threat to public health because of the slow progress in developing new antimicrobial, which can be used for therapy when resistance occurs. ${ }^{4,5}$

Nevertheless, most studies on the emergence and spread of antibiotic resistance are focused mainly on clinically relevant bacterial species. Infections caused by resistant strains, in fact, are more difficult to treat and require more time and money for their control. ${ }^{6,7}$ In addition, genes encoding antibiotic resistance are also detected in bacteria isolated from uncontaminated and non-urbanized environments. ${ }^{8}$

Antibiotic resistance can be inherent in a bacterial species, which has been termed as intrinsic or natural resistance and/or acquired when a usually susceptible strain or susceptible species becomes resistant. ${ }^{9}$ Intrinsic resistance is chromosomally regulated and is linked to the microorganism physiology. ${ }^{10}$ Acquired resistance occurs through mutations in the genes encoding the antimicrobial target site or acquisition of resistance-encoding genetic material through mobile genetic elements such as plasmids, integrons, bacteriophages and transposons. ${ }^{11,12}$ Horizontal gene transfer can happen through three independent mechanisms: conjugation, considered the most effective, transduction and transformation. ${ }^{2}$

Selective pressure imposed by the intensive use of antimicrobials has had an impact not only on pathogens but also on non-pathogenic and commensal strains. ${ }^{13}$ Pathogens that carry resistance genes constitute a direct threat to humans and animal health while non-pathogenic and opportunistic bacteria represent an indirect threat, as their harbor resistance genes that can be transferred to pathogens through horizontal gene transfer. ${ }^{14}$ Consequently, bacteria, act as reservoir of resistance genes and influence the dissemination of antimicrobial resistance-encoding genes in the microbial ecosystem. Scott stated that gene transfer occurs widely in vivo between gastrointestinal tract microbiota and pathogens. ${ }^{15}$ The food chain can be considered one of the routes for antibiotic-resistance gene transfer between animals and humans. ${ }^{6}$

In the last decades, research has demonstrated the presence of antimicrobial resistance genes in Lactobacillus spp., ${ }^{16}$ and Bifidobacterium spp. ${ }^{17}$ but information on the antimicrobial susceptibility profiles of Leuconostoc spp. are scarce. ${ }^{18}$

Leuconostoc spp. are heterofermentative lactic acid bacteria, which occur in a large variety of food as commensals. Leuconostoc belong to Leuconostoc-Weissella group. Leuconostoc are detected during manufacturing and ripening of several fermented foods and beverages. Leuconostoc have been used in dairy technology for technological and biological beneficial effects. ${ }^{19}$ However, in meat products they could be responsible of undesirable modifications and alterations such as slime formation. ${ }^{20}$ Leuconostoc spp. is considered a generally regarded as safe (GRAS) microorganism. ${ }^{21}$ However in immunocompromised patients it can indirectly represent a threat by mediating antimicrobial resistance transfer. ${ }^{16,22}$ Leuconostoc spp. grow at refrigeration temper-
Correspondence: Maria Francesca Iulietto, Department of Veterinary Medicine, University of Perugia, via San Costanzo, 06126 Perugia, Italy. Tel.: +39.075.5857935 - Fax: +39.075 .5857976$

E-mail:mf.iulietto@gmail.com

Key words: Leuconostoc mesenteroides; antibiotic resistance; disk diffusion susceptibility test.

Contributions: the authors contributed equally.

Conflict of interest: the authors declare no potential conflict of interest.

Received for publication: 23 March 2016.

Revision received: 14 April 2016

Accepted for publication: 2 May 2016

This work is licensed under a Creative Commons Attribution NonCommercial 4.0 License (CC BYNC 4.0).

(C) Copyright M.F. Iulietto et al., 2016

Licensee PAGEPress, Italy

Microbiology Research 2016; 7:6519

doi:10.4081/mr.2016.6519

atures $\left(2-4^{\circ} \mathrm{C}\right) \cdot{ }^{23,24}$ At low temperature Leuconostoc spp. can survive and compete with other strains. ${ }^{25}$ A typical characteristic of the species of the Leuconostoc-Weissella group have been shown to have intrinsic and non transferable resistance against glycopeptides, including vancomycin. ${ }^{26}$ Resistance against vancomycin and other glycopeptides is determined by the presence of the dipeptide DAlanine-D-Lactate as constituent of their peptidoglycan instead of the D-Alanine-D-Alanine dipeptide. ${ }^{27}$ The aim of the this study was to investigate the antimicrobial susceptibility patterns of ropy slime-producers L.mesenteroides isolates, which were recovered from commercial cooked ham, through disk diffusion test. The aim is to monitor antimicrobial resistance and assess the risk posed by Leuconostoc mesenteroides isolates in the transfer of antimicrobial resistance.

\section{Materials and Methods}

Commercial cooked ham marketed in Italy and affected by ropy slime was sampled and examined for the occurrence of slime-producing bacteria. The detection of ropy slime-producing bacteria was conducted through biochemical and biomolecular analysis (PCR and sequencing). According to the phenotypic and genotypic findings, two strains of ropy slimeproducing Leuconostoc mesenteroides were isolated, identified and classified as 649 and 650 (Laboratory collection ID). Briefly, isolates 
were plated on selective agar, i.e. MRS agar (Oxoid, CM0361) added with vancomycin (20 $\mathrm{g} / \mathrm{mL}$ ) at $30^{\circ} \mathrm{C}$ for 48 hours, in microaerophilic conditions. Then, Leuconostoc mesenteroides was detected according to PCR conditions indicated by Robert and colleagues, ${ }^{28}$ with primers which target the 16S rRNA gene: L.mesF (5'AACTTAGTGTCGCATGAC-3') and L.mesR (5'AGTCGAGTTACAGACTACAA-3'). According to Yost and Nattress, ${ }^{29}$ universal primers Y1 (5'TGGCTCAGAACGAACGCTGGCCCG-3') and Y2 (5'-CCCACTGCTGCCTCCCGTAGGAGT-3') for bacterial 16S rRNA gene were used as positive control to ensure that template DNA was readily amplifed; primers Lu1r (5'-CCACAGCGAAAGGTGCTTGCAC-3') and Lu2 (5'-GATCCATCTCTAGGTGACGCCG-3') were used to specifically amplify a fragment of approximately 175 bp from Leuconostoc spp. Amplification products were sent for sequencing (Table 1).

\section{Disk diffusion susceptibility test}

Antimicrobial resistance patterns were determined against a panel of 21 antibiotics, using the disk diffusion test (Kirby-Bauer) with antimicrobial susceptibility disks (Thermo Scientific ${ }^{\mathrm{TM}}$, 0xoid, Waltham, MA, USA) (Table 2). The antibiotics were selected and disk diffusion patterns were evaluated according to the microbiological breakpoints for selected lactic acid bacteria as defined by EFSA (2012). ${ }^{16}$ The antibiotics used for this study were cell wall synthesis, nucleic acid synthesis, folate synthesis and protein synthesis inhibitors. The agar disk diffusion method was performed on Mueller Hinton agar (Oxoid, CM0337), according to Clinical and Laboratory Standards Institute guidelines. ${ }^{30}$

The inoculum was prepared from colonies on a primary culture plate. The strains $(n=2)$ of the Laboratory Collection, previously isolated, were inoculated into MRS broth, incubated at $30^{\circ} \mathrm{C}$ for $24 \mathrm{~h}$. The cell density of the cultures was adjusted to approximately $1 * 10^{8} \mathrm{cfu}$ $\mathrm{mL}^{-1}$, equivalent to an absorbance at $600 \mathrm{~nm}$ of 1668 0D. The broth was transferred on diluent solution until 0.5 McFarland Standard. Mueller-Hinton agar plates were inoculated by dipping a sterile swab into the solution, removing the excess against the side of the tube; followed by streaking the swab all over the surface of the medium three times, by rotating the plate through an angle of $60^{\circ}$ after each application. Within 15 minutes of swabbing, four antibiotic disks were placed aseptically on the agar surface. Agar plates with antibiotic disks were then incubated for $24 \mathrm{~h}$ at $30^{\circ} \mathrm{C}$, under anaerobic conditions. After overnight incubation, the diameters of the inhibition zones were measured using a ruler under a colony counter apparatus and the results were recorded in mm. The result was interpreted according to CLSI standard criteria. ${ }^{30}$

\section{Results}

Antimicrobial susceptibility was evaluated using zone diameter interpretive criteria after an average of 2 readings. Isolates were expressed as sensitive (S), intermediate (I) and resistant (R) according to CLSI published breakpoint interpretations based on pharmacokinetic and pharmacodynamic data. ${ }^{30}$ Results are summarised in Table 2.

\section{Susceptibility to inhibitors of cell wall synthesis}

The isolates showed resistance towards all $\beta$-lactams including ampicillin, and methicillin except for ticarcillin. Resistance was also observed against cephalosporins tested i.e. cefotaxime, ceftriaxone, cephalotin. Assays for $\beta$-lactamase inhibitors revealed resistance to amoxicillin-clavulanic acid. All isolates were resistant to vancomycin.

\section{Susceptibility to inhibitors of nucleic acid synthesis}

Strains were resistant to sulphamethoxazole-trimethoprim and sulphonamide. Concerning quinolones, the isolates were resistant to nalidixic acid, but susceptible to enrofloxacin and cyprofloxacin

\section{Susceptibility to protein synthesis inhibitors}

All strains were susceptible to tetracycline, to chloramphenicol and to erythromycin. The

Table 1. Leuconostoc mesenteroides Genbank accession number and nucleotide sequences of the $16 S$ rRNA gene.

\begin{tabular}{|c|c|c|c|}
\hline Strains & ID & $\begin{array}{c}\text { GenBank } \\
\text { accession number }\end{array}$ & $\begin{array}{l}\text { Nucleotide sequences of the } 16 \mathrm{~S} \text { rRNA } \\
\text { gene }\end{array}$ \\
\hline $\begin{array}{l}\text { Leuconostoc } \\
\text { mesenteroides }\end{array}$ & 649 & КС568533.1 & $\begin{array}{c}\text { CWWTKGAGYMTGCGMACTAAGTTTTATTCGGTATTAGCATC } \\
\text { TGTTTCCAAATGTTATCCCCAGCCTTGAGGCAGGTTGTCCAC } \\
\text { GTGTTACTCACCCGTTCGCCACTCACTTGAAAGGTGCAAGCA } \\
\text { CCTTTCGCTGTGGA }\end{array}$ \\
\hline $\begin{array}{l}\text { Leuconostoc } \\
\text { mesenteroides }\end{array}$ & 650 & gblM23035.1l & $\begin{array}{c}\text { CTWATTTGKGYMTGCGAMACTAAGTTTTATTCGGTATTAGC } \\
\text { ATCTGTTTCCAAATGTTATCCCCAGCCTTGAGGCAGGTTGTC } \\
\text { CACGTGTTACTCACCCGTTCGCCACTCACTTGAAAGGTGCAA } \\
\text { GCACCTTTCGCTGTGGA }\end{array}$ \\
\hline
\end{tabular}

Table 2. Antimicrobials disks used in susceptibility assay and susceptibility profiles of strains of Leuconostoc mesenteroides.

Antimicrobials Concentration, Mg/disk Leuconostoc mesenteroides

Cell wall synthesis inhibitors

Amoxicillin/clavulanic acid

Ampicillin

Cefotaxime

Ceftriaxone

Cephalothin

Methicillin

Ticarcillin

Vancomycin Concentration, $\mu g / d i s k$ Leuconostoc mesenteroides

Nucleic acid synthesis inhibitors

Cyprofloxacin

Enrofloxacin

Nalidixic acid

Chloramphenicol

$\begin{array}{cc}20-10 & \mathrm{R} \\ 10 & \mathrm{R} \\ 30 & \mathrm{R} \\ 30 & \mathrm{R} \\ 30 & \mathrm{R} \\ 5 & \mathrm{R} \\ 75 & \mathrm{~S} \\ 30 & \mathrm{R}\end{array}$

Folate synthesis inhibitors

Compound sulphonamides

Sulphamethoxazole/trimethoprim

$\begin{array}{cc}5 & \mathrm{~S} \\ 5 & \mathrm{~S} \\ 30 & \mathrm{R} \\ 30 & \mathrm{~S}\end{array}$

Protein synthesis inhibitors

$\begin{array}{lll}\text { Erythromycin } & 15 & \text { S } \\ \text { Tetracycline } & 30 & \text { S } \\ \text { Amikacyn } & 30 & \text { S } \\ \text { Gentamicin } & 10 & \text { S } \\ \text { Kanamycin } & 30 & \text { S } \\ \text { Neomycin } & 30 & \text { S } \\ \text { Streptomycin } & 10 & \text { I }\end{array}$

R, resistant; I, marginally susceptible; S, susceptible. 
isolates were also susceptible to the following aminoglycosides: gentamicin, neomicyn, amikacyn and kanamycin. Finally, susceptibility was observed for all the inhibitors of protein synthesis tested with the exception of partial resistance to streptomycin.

\section{Discussion and Conclusions}

Comparing to data reported in previous studies, our results showed that ropy slimeproducing L.mesenteroides strains were resistant to $\beta$-lactams and susceptible to chloramphenicol, kanamycin and partially resistant to streptomycin. Concerning resistance to glycopeptides, nalidixic acid, gentamicin, kanamycin, streptomycin and sulphamethoxazhole/thrimetroprim and susceptibility to chloramphenicol, erythromycin and tetracycline our results are in accordance with previous studies. ${ }^{16,27,31}$

The effects of antibiotic resistance represent a major health concern even if it is a common characteristic in bacteria; further assessment in the ecology of the phenomenon is required. ${ }^{32}$ The transmission of antibiotic resistance genes to other organisms is one the most important safety issues because the food chain is considered as one of the paths for the diffusion antibiotic resistance-encoding genes. ${ }^{6}$ When considering microbiota interaction, genetic material is shifted from one strain to another, and also genes coding for resistance to a certain antibiotic may be transferred to other species. ${ }^{18}$

Nowadays, increased attention is given to food safety, taking into account all the bacteria present in food products. Lactic acid bacteria naturally occur in many environments, including vegetables, meat, gastrointestinal tract, and strains with multi-drug resistance-encoding genes constitute a potential threat for the wellbeing of humans or animals. ${ }^{6}$ Naturally present or intentionally added lactic acid bacteria represent a source of antibiotic resistance determinants for potentially pathogenic strains through horizontal gene transfer. ${ }^{5,7}$ Ropy slime producing bacteria are responsible of spoilage of cooked meat products and, in association with the abundant secretion of exopolysaccharides, they maintain a stationary phase which persist for the entire shelf life of the product. The attention to these strains is not only due to the economical impact of the spoilage they provokes but also for investigating the potential risk of transmission of antibiotic-resistance genes to pathogens, considering their multi-drug resistance. In fact, when the phenomenon of ropy slime is not evident and the product reaches the final consumer, the risk is enhanced.

\section{References}

1. Fleming A. On the antibacterial action of cultures of a penicillium, with special reference to their use in the isolation of $B$. influenzæ. Br J Exp Pathol 1929;10:226-36.

2. Cambiotti V, Romagnoli P, Sorice A, et al. [I meccanismi con cui i batteri resistono agli antimicrobici]. Argomenti 2014;7:71-80. [Article in Italian]

3. Romagnoli P, Cenci Goga BT, Sorice A. [L'impegno dei veterinari della sanità pubblica in un problema mondiale]. Argomenti 2014;1:41-50. [Article in Italian]

4. Rosenblatt-Farrell N. The landscape of antibiotic resistance. Environ Health Perspect 2009;117:A244-50.

5. Toomey N, Bolton D, Fanning S. Characterisation and transferability of antibiotic resistance genes from lactic acid bacteria isolated from Irish pork and beef abattoirs. Res Microbiol 2010;161: 127-35.

6. Patel AR, Shah NP, Prajapati JB. Antibiotic resistance profile of lactic acid bacteria and their implications in food chain. World J. Dairy Food Sci 2012;7:202-11.

7. Sharma P, Tomar SK, Goswami P, et al. Antibiotic resistance among commercially available probiotics. Food Res Int 2014;57: 176-95.

8. Cambiotti V, Garofalo D, Cenci Goga BT. [Comparison between tetracycline resistant enterococci isolated from sheep and typical cheese in the geographical area of Parco nazionale dei Monti Sibillini]. It J Food Safety 2012;1:43-8. [Article in Italian ]

9. Cox G, Wright GD. Intrinsic antibiotic resistance: mechanisms, origins, challenges and solutions. Int $\mathrm{J}$ Med Microbiol 2013;303:287-92.

10. Belletti N, Gatti M, Bottari B, et al. Antibiotic resistance of lactobacilli isolated from two italian hard cheeses. J Food Prot. 2009;72:2162-9.

11. Bennett PM. Plasmid encoded antibiotic resistance: acquisition and transfer of antibiotic resistance genes in bacteria. $\mathrm{Br}$ J Pharmacol 2008;153:S347-S57.

12. Devirgiliis C, Zinno P, Perozzi G. Update on antibiotic resistance in foodborne lactobacillus and lactococcus species. Front Microbiol 2013;4:301.

13 Agarwal M, Garg F, Negi Y. Antibiotic resistance and plasmid profile of Leuconostoc spp. isolated from carrot. J Bacteriol Res 2014;6:7-12.

14. Courvalin P. Antibiotic resistance: the pros and cons of probiotics. Dig Liver Dis 2006;38:S261-5.

15. Scott KP. The role of conjugative trans- posons in spreading antibiotic resistance between bacteria that inhabit the gastrointestinal tract. Cell Mol Life Sci 2002;59:2071-82.

16. Korhonen J. Antibiotic Resistance of Lactic Acid Bacteria. Kuopio: University of Eastern Finland; 2010.

17. D’Aimmo MR, Modesto M, Biavati B. Antibiotic resistance of lactic acid bacteria and bifidobacterium spp. isolated from dairy and pharmaceutical products. Int $\mathrm{J}$ Food Microbiol 2007;115:35-42.

18. Flórez AB, Campedelli I, Delgado S, et al. Antibiotic susceptibility profiles of dairy leuconostoc, analysis of the genetic basis of atypical resistances and transfer of genes in vitro and in a food matrix. PLoS One 2016;11:e0145203.

19. Cardamone L, Quiberoni A, Mercanti DJ, et al. Adventitious dairy leuconostoc strains with interesting technological and biological properties useful for adjunct starters. Dairy Sci Technol 2011;91:457-70.

20. Iulietto MF, Sechi P, Borgogni E, CenciGoga BT. Meat spoilage: a critical review of a neglected alteration due to ropy slime producing bacteria. It J Anim Sci 201;14: 316-26.

21. Holland R, Liu SQ. Leuconostoc spp. Amsterdam: Elsevier Ltd; 2011. pp 138-42.

22. Fraqueza MJ. Antibiotic resistance of lactic acid bacteria isolated from dry-fermented sausages. Int J Food Microbiol 2015; 212:76-88.

23. Vermeiren L, Devlieghere F, Debevere J. Evaluation of meat born lactic acid bacteria as protective cultures for the biopreservation of cooked meat products. Int J Food Microbiol 2004;96:149-64.

24. Sade E, Murros A, Bjorkroth J. Predominant enterobacteria on modifiedatmosphere packaged meat and poultry. Food Microbiol 2013;34:252-8.

25. Iulietto MF, Sechi P, Borgogni E, CenciGoga BT. Evolution under different growth conditions of ropy slime-producing bacteria isolated from cooked meat products. in Proceedings of the LXIX Convegno S.I.S.Vet, 2015 Jun 15-17, Perugia, Italy. p 233

26. Zdolec N, Filipovi I, Cvrtila Fleck Ž, et al. Antimicrobial susceptibility of lactic acid bacteria isolated from fermented sausages and raw cheese. Veterinarski Arhiv 2011;81:133-41.

27. Hemme D, Foucaud-Scheunemann C. Leuconostoc, characteristics, use in dairy technology and prospects in functional foods. Int Dairy J 2004;14:467-94.

28 Robert H, Gabriel V, Fontagne-Faucher C. Biodiversity of lactic acid bacteria in French wheat sourdough as determined by molecular characterization using speciesspecific PCR. Int $\mathrm{J}$ Food Microbiol 
2009;135:53-9.

29. Yost CK, Nattress FM. The use of multiplex PCR reactions to characterize populations of lactic acid bacteria associated with meat spoilage. Lett Appl Microbiol 2000;31:129-33.

30. CLSI. Performance standards for antimi- crobial susceptibility testing. 21st informational supplement CLSI M100-S21 ed, Wayne, PA; 2011.

31. Flórez AB, Campedelli I, Delgado S, et al. Antibiotic susceptibility profiles of dairy leuconostoc, analysis of the genetic basis of atypical resistances and transfer of genes in vitro and in a food matrix. PLoS One 2016;11:e0145203.

32. Nawaz M, Wang J, Zhou A, et al. Characterization and transfer of antibiotic resistance in lactic acid bacteria from fermented food products. Curr Microbiol 2011;62:1081-9. 